\title{
DOES THE DEVELOPMENT DISCOURSE LEARN FROM HISTORY?
}

Albert Sanghoon Park ${ }^{1}$

\begin{abstract}
What is the nature and extent of historical awareness in the development discourse? Does the development discourse learn from history, including its own? Set in the contexts of aging development institutions and a changing geopolitical climate, this paper provides one account through a historiographical survey of 136 journal articles across 10 leading development journals. It uncovers a substantial body of works, which offer descriptive histories, derivative lessons, and historiographical critiques. Altogether, they evidence two modes in which the development discourse attempts to learn from history. The first lies in the proactive use of external histories as empirical evidence for a variety of development issues. This is the predominant mode exhibited in the survey. A second mode lies in the use of internal histories of the development discourse, itself. Here, the survey finds a number of noteworthy but largely disparate efforts. This suggests a relative dearth in historiographical selfconsciousness for a narrow but influential segment of the development discourse. A number of consequences are considered, ultimately responding to the legitimacy, efficacy, and sustainability of development action. In sum, our survey finds that the mainstream development journal discourse is adept at learning from external histories, but not necessarily from its own. Evidence, however, suggests that it can. A case is made for why it must.
\end{abstract}

Keywords development history, historiography, discourse analysis, development policy

\footnotetext{
${ }^{1}$ PhD Candidate, Centre of Development Studies, University of Cambridge. Email: ahp36@cam.ac.uk

This work was based out of the Ralph Bunche Institute for International Studies, City University of New York; the Programme for the Study of International Governance, Graduate Institute, Geneva; and the Kyujanggak Institute for Korean Studies, Seoul National University. In addition to these communities, the author is further grateful to three anonymous reviewers for their constructive feedback.
} 


\section{CONTENTS}

1 INTRODUCTION

2 METHODOLOGY

2.1 Discourse analysis

2.2 Data selection

3 SURVEY FINDINGS

3.1 Descriptive historical analysis

3.2 First-order historical analysis

3.3 Second-order historical analysis

4 DISCUSSION

4.1 Does the development discourse learn from history?

4.2 Why does this matter?

4.3 What does development history do well?

4.4 What now?

5 CONCLUSION

\section{INTRODUCTION}

What is the nature and extent of historical awareness in the development discourse? Does the development discourse learn from history, or does it ignore the past to be, in George Santayana's words, 'condemned to repeat it' (Santayana, 1905: 284)? These questions carry particular significance in light of two present contexts. The first is a development enterprise (encompassing both theory and practice) that has marked 70 years in its post-World War history. As it now enters its eighth decade, it seems fitting to reflect upon the history of development — and upon development's own awareness of it.

The second context motivating this work is a geopolitical climate that is markedly different from the one in which the post-World War development enterprise was originally built. Old geopolitics of decolonisation and the Cold War have been replaced by narratives on hegemony and rising powers. Further, the grand optimism and early hopes in development have been replaced by a more reserved sort of development buffeted in a sea of discontent. Recent years, in particular, speak volumes about such discontents - with globalisation and elite cosmopolitanism, prolonged economic and humanitarian crises, and rising insecurities for countries both 'developing' and 'developed'. Changing operational contexts have, in turn, spurred calls for reform (e.g. Malloch-Brown, 2014; Weiss \& Abdenur, 2014) and even wholesale abandonment (e.g. Esteva, 2010; Sachs, 2010; Escobar, 2011) of the development enterprise.

Altogether, these contexts raise serious concerns in regards to development's future. What will become of development? What should it be? How can it be changed? When faced with such uncertainties about the future, it is useful to reflect upon the past. How did we get here? Why are things done the way they are? What have we learned? It is with such questions in mind that this work 
delves into the history of development. It cannot provide a comprehensive answer, being limited in a number of aspects. Most tellingly, it comments only on the peer-reviewed English-language journal literature. The aim is thus to provide but a glimpse into the development discourse's knowledge of the past. In light of the timeliness of such a work, however, even a brief glimpse may yet be a valuable one.

The remainder of this work proceeds as follows. Section two explains the study's methodology and associated limitations. Section three summarizes findings from our survey of the journal literature. Section four then discusses the broader significance of said findings. Finally, section five concludes with a summary and suggestions for future work.

\section{METHODOLOGY}

The methods of this work borrow from intellectual history to examine how the development discourse engages with history, writ large. Namely, it engages in a form of discourse analysis that traces not a pre-determined school of thought or thinkers, but rather the broader flow of arguments across a number of arenas or sub-streams in development thought. The methods and underlying rationale are presented at length, below.

\subsection{Discourse analysis}

First of all, how are we to answer the question of whether the development discourse learns from history? Let us first begin with some groundwork: (1) what exactly do we mean by the development discourse, and (2) what exactly do we mean by learning from history?

For (1), we define the development discourse as the collective stream of ideas or thought engaging with development theory and practice. In this work, we focus on the academic discourse of development studies. This includes contributions from across the social sciences (e.g. anthropology, economics, geography, politics, sociology) and other allied disciplines (e.g. history, philosophy, gender studies, environmental studies). Further, we focus on this discourse as it manifests in written form. This allows us to subdivide the field into journals, books (e.g. monographs, edited volumes, textbooks), and the so-called gray literature (e.g. working papers, reports, conference proceedings, dissertations). This study focuses on journals, but for reasons that first require us to specify what we mean by 'learning from history'.

For (2), we adopt a rather minimalist stance on learning from history. 'Learning' in a discourse could be evidenced in any number of ways, from the gradual accumulation and refinement of some store of knowledge to the drastic paradigm shifts in scientific revolutions and overturned worldviews. Here, we adopt a bare and open-ended conception of learning in asking how and to extent the development discourse derives knowledge from history, writ large. Beyond this, we find little need to ascribe to any one particular mode of learning; for doing so, in a way, defeats the very purpose of this present exercise. 
Having specified our aims, we now return to explaining our choice in (1) to focus on journal articles. To be explicit, journal articles are hardly chosen here to be representative of the development discourse in its entirety. However, journal articles offer two key benefits when investigating how development learns from history.

First, journal articles enable a level of temporal-spatial resolution for our survey that is difficult to achieve with the book-format literature. The latter entails comparatively large commitments of time and energy, which carry disadvantages in terms timely and comprehensive representation. The obvious drawback here is the exclusion of a sizeable body of historical works. Examples include Arndt (1989); Jolly, Emmerij, Ghai, \& Lapeyre (2004); Leys (1996); Meier (2004); Pieterse (2010); Preston (1999); Rapley (1997); Rist (2014); and Ziai (2015). These sources warrant a separate study of their own, but journal articles prove more optimal for an initial survey. That said, these very same advantages could also be attributed to the gray literature, as well. It is here, however, that the journal literature's second benefit comes to the fore.

Second, journal articles allow us to note the relative influence of certain arguments in the broader politics of development thought. This stems from the academic journal's key role in mediating development knowledge. That is, academic journals entail distinct (but frequently overlapping) substreams or sub-discourses in terms of the sociology and politics of knowledge. This is rendered by the selection or curation process of each journal's editorial staff and peer-review community, which in turn imparts published articles with an implicit measure of value or recognition. This process is further reinforced by the key role of journal publications - particularly journal impact factors and article citations - when it comes academic hiring and promotion. Ultimately, this dissemination and competition of ideas across what Collins (2009) refers to as a 'limited attention space' also come to influence the very ideas that matter in the realm of development policy and practice. This legitimacy and influence is where our comparatively unregulated gray literature falls short. This is not to say, however, that such literature has not been influential (e.g. the UN Brundtland Report on sustainable development), and entails yet another limitation to this study.

Finally, when it comes to methodological limitations, it must also be pointed out that this study can only speak of the English-language development discourse. Little can be said of the ideas and debates occupying other development discourses (e.g. Spanish, French, German, Korean); nor of the international flow of ideas and the political relations to be observed between them. With that said, the English-language discourse is hardly exclusive to Anglo-American views. As a de facto lingua franca, many 'foreign' (e.g. non-Anglophone, non-Western) perspectives are to be found. Indeed, foreignlanguage monographs are often translated and abridged into journal articles for wider dissemination in the English-language discourse. This possibly adds another benefit to surveying journal articles over books. Nevertheless, while the English-language development discourse may be relatively inclusive, it is not held to be representative of the global development discourse, on the whole. Consequently, some level of Anglo-American bias is to be expected. 


\subsection{Data selection}

The basic approach for gathering survey data was to compile journal articles with some variant of the term 'history' (e.g. historic, historical, histories, historiography) in the title and/or keywords. This was conducted using a wildcard search term ('histor*'), but required — due to pure volume - further culling of search results. Given the aim of this work to identify representative or, alternatively, predominant ways in which history has been used in the development discourse, a second selection criterion was introduced: journal impact factors.

Journal impact factors were referenced from the latest Journal Citation Reports@ Social Sciences Edition, published annually by Thomson Reuters (2016). Journals were then retrieved from the category of 'Planning and Development' and filtered to remove journals focused on planning, as opposed to development (e.g. urban planning, management science, public administration). ${ }^{2}$ Out of the remaining journals, the top 10 were selected based on highest 5-year impact factors (encompassing 2011-2015; see Table 1).

Table 1. Survey panel of ten top development journals (by 5-year impact factor)

\begin{tabular}{llc}
\hline $\begin{array}{l}\text { 5-year Impact Factor } \\
(2011-2015)\end{array}$ & Journal Title & First Issue \\
\hline 3.102 & World Development & 1973 \\
2.268 & Sustainable Development & 1993 \\
2.251 & Development and Change & 1970 \\
2.075 & World Bank Research Observer & 1986 \\
2.057 & World Bank Economic Review & 1986 \\
1.638 & Economic Development and Cultural Change & 1952 \\
1.381 & Third World Quarterly & 1979 \\
1.253 & Journal of Development Studies & 1964 \\
1.245 & Studies in Comparative International Development & 1965 \\
1.178 & Progress in Development Studies & 2001 \\
\hline Source: 2015 Journal Citation Reports® Social Science Edition (Thomson and Reuters. 2016)
\end{tabular}

With the search domain narrowed down to what might be characterised as the most frequently cited or the most 'mainstream' journals in the development discourse, a new search produced a more manageable but sufficiently large sample set $(n=136)$ of original research articles, editorials, and special issue introductions. Table 2 provides an overview of their distribution across journals and across time.

\footnotetext{
${ }^{2}$ The category of 'Planning and Development' is defined by Thomson Reuters (2016) as follows: "Planning \& Development is concerned with resources on the economics and social development of both underdeveloped and industrialized areas. The resources in this category focus on subjects such as economic forecasting, development studies, policy-making strategies, theories of planning, and the growth of the third world."
} 
Table 2. Distribution of surveyed articles (by journal, time)

\begin{tabular}{|c|c|c|c|c|c|c|c|c|c|c|c|c|c|c|c|c|}
\hline \multicolumn{17}{|c|}{ Est. Journal } \\
\hline 1952 & Economic Development and Cultural Change & 3 & 0 & 1 & 0 & 1 & 1 & 1 & 1 & 1 & 0 & 1 & 1 & 0 & 0 & $\begin{array}{l}\text { tot } \\
11\end{array}$ \\
\hline 1964 & Journal of Development Studies & & & 0 & 1 & 0 & 0 & 3 & 1 & 0 & 1 & 1 & 1 & 4 & 0 & 12 \\
\hline 1965 & Studies in Comparative International Development & & & 0 & 0 & 2 & 1 & 1 & 1 & 1 & 0 & 1 & 2 & 0 & 0 & 9 \\
\hline 1970 & Development and Change & & & & 0 & 1 & 1 & 1 & 1 & 1 & 6 & 5 & 0 & 1 & 0 & 17 \\
\hline 1973 & World Development & & & & & 1 & 1 & 1 & 3 & 4 & 5 & 2 & 7 & 8 & 1 & 33 \\
\hline 1979 & Third World Quarterly & & & & & & 0 & 2 & 0 & 3 & 5 & 8 & 9 & 10 & 0 & 37 \\
\hline 1986 & World Bank Economic Review & & & & & & & & 0 & 0 & 1 & 1 & 0 & 0 & 0 & 2 \\
\hline 1986 & World Bank Research Observer & & & & & & & & 2 & 0 & 0 & 2 & 0 & 0 & 0 & 4 \\
\hline 1993 & Sustainable Development & & & & & & & & & 0 & 1 & 1 & 0 & 3 & 0 & 5 \\
\hline 2001 & Progress in Development Studies & & & & & & & & & & & 0 & 1 & 5 & 0 & 6 \\
\hline & TOTAL $(n=136)$ & 3 & 0 & 1 & 1 & 5 & 4 & 9 & 9 & 10 & 19 & 22 & 21 & 31 & 1 & \\
\hline
\end{tabular}

Note: Establishment year corresponds to the year of each journal's first issue; publication statistics for 2016 are incomplete, and cover only the period from January 1 - September 19, 2016.

\section{SURVEY FINDINGS}

Perhaps the most immediate finding of our survey was the sheer variety of historical works found in the development literature. Example dimensions of variation included subject matter, geographical focus, time period, research methods, and intellectual or ideological stance. Further compounding this variety were multiple senses in which a work could be referred to as 'historical'. Specifically, three types of historical analysis were found.

The first type consisted of descriptive historical accounts of some form. Example works include a history of migrant labour in Mauritius (Kothari, 2013) or the history of the idea of agricultural selfsufficiency (Morrissey, 1982). Such works were typically—though not necessarily—followed by a second type of historical analysis.

This second type entailed historical lessons or first-order historical analyses that were often derived from descriptive historical accounts. Examples include historical lessons for monetary and fiscal policies to counter hyperinflation (Solimano, 1990) and guidance on land reform for postapartheid South Africa (Binswanger \& Deininger, 1993).

Finally, the third type of history is referred to as historiographical or second-order historical analysis, in reference to its greater abstraction or critical reflection relative to the previous two types. Second-order analyses often addressed broader questions on how and why to do development history. Examples include arguments on what development stands to gain from history (e.g. Adelman \& Morris, 1997; Woolcock, Szreter, \& Rao, 2011) and on how not to do history (e.g. Hopkins, 1986; Leach \& Fairhead, 2000; Niemeijer, 1996). Second-order analysis was often premised on descriptive and first-order arguments, though the direction across types was rather cyclical and could go both ways (see Figure 1). 


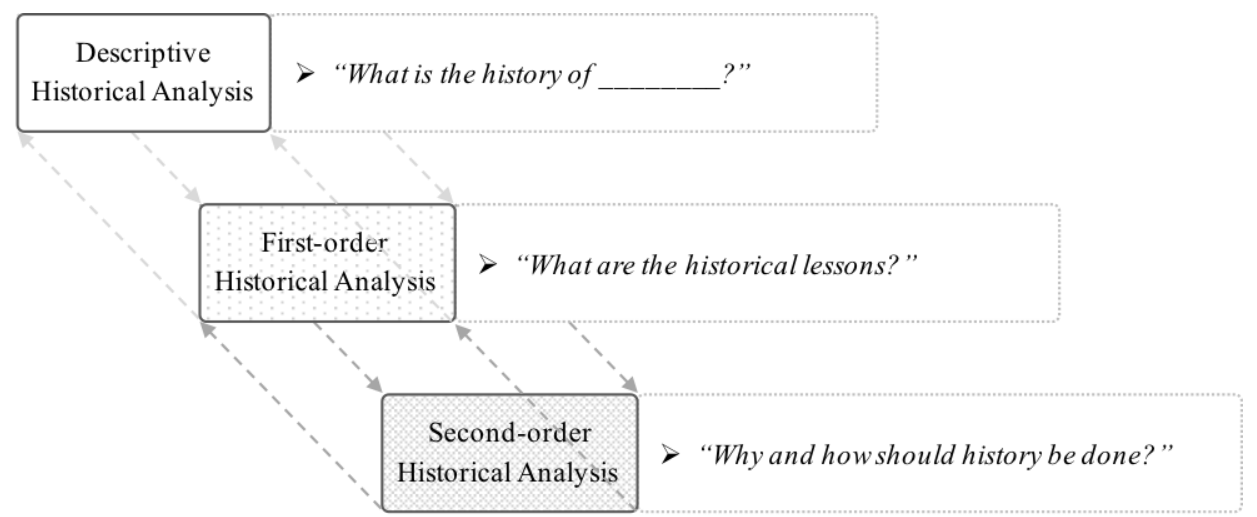

Figure 1. Typology of historical analyses rendered from surveyed works

The survey findings that follow are structured according to this basic typology. Works that included multiple types of analysis (which was typically the case) were disaggregated and reviewed accordingly. Thus, section 3.1 presents a review across all of the survey's descriptive accounts. Section 3.2 follows with a review of first-order lessons, while section 3.3 closes with second-order historiographical arguments.

\subsection{Descriptive historical analysis}

\section{(a) Variation across development topic}

The surveyed histories reflected the wide variety of topics covered in development, with a sample of recurring themes presented in Table 3. Of these, particular subjects received more attention than others. Six prominent themes are highlighted here: (1) agricultural/rural and industrial/urban development; (2) land/property rights; (3) colonialism; (4) technology and innovation; (5) the global economy; and (6) migration.

Table 3. Survey of development histories

\begin{tabular}{|c|c|}
\hline Historical Subject & Sample References \\
\hline agricultural and/or rural development & Graulau, 2008; Lu \& Lora-Wainwright, 2014; Wiemers, 2015 \\
\hline industrial and/or urban development & Lampard, 1955; Schmitz, 1984; Wood \& Jordan, 2000 \\
\hline - on the relationship between the above two & Arrighf, 1970; Harriss \& Harriss, 1984; Udall, 1980 \\
\hline land reform, common property, property rights & Edelman \& León, 2013; Johnson, 2014; Runge \& Defrancesco, 2006 \\
\hline ecology, environment, and sustainability & Goossens, 1997; Hayami, 2001; McDaniel, 2003 \\
\hline technology and/or innovation & Binswanger, 1986; Lybæk, Christensen, \& Kjær, 2013; Parker, 1961 \\
\hline trade and development & Mushtaq, 2015; Özler, Taymaz, \& Yilmaz, 2009; Sandberg, Seale, \& Taylor, 2006 \\
\hline macroeconomic policy & Dooley, Fernandez-Arias, \& Kletzer, 1996; McLure, 1992; Solimano, 1990 \\
\hline development administration & Goode, 1993; Hirschmann, 1999; Singer, 1953 \\
\hline poverty and/or inequality & Logan, Tengbeh, \& Petja, 2012; Ludden, 2012; Williamson, 1979 \\
\hline public health and welfare & Bishai \& Nalubola, 2002; Chaiken, 1998; Gooch, 2016 \\
\hline education and development & Gellman, 2015; Wietzke, 2014, 2015 \\
\hline gender and development & Benjamin \& Brandt, 1995; de Haan, 2002 \\
\hline internal colonialism & Alcántara, 1974; Love, 1989; Peralta \& Hollenstein, 2015 \\
\hline globalisation & Broad \& Heckscher, 2003; Bunker \& Ciccantell, 2003; Cardoso, 2009 \\
\hline migration & Dobby, 1952; Gottschang, 1987; Hatton \& Williamson, 2008 \\
\hline human rights and law & Dawson, 2013; Robertson, 1982; Szreter, 2007; Waltz, 2002 \\
\hline NGOs and civil society & Beauchemin \& Shoumaker, 2009; Fowler, 2000; Lewis, 2008 \\
\hline democracy and development & Blaney \& Pasha, 1993; Gerring, Kingstone, Lange, \& Singha, 2011; Omgba, 2015 \\
\hline institutions and development & Hoff, 2003; Iverson, Palmer-Jones, \& Sen, 2013; North, 1989; Wietzke, 2015 \\
\hline peace and security & Akhavi, 2003; Arquilla, 2007; Bieber, 2000 \\
\hline US hegemony & Beeson \& Higgott, 2005; Connell-Smith, 1984; Munro, 2014 \\
\hline state- or nation-building & Bilgin \& Morton, 2002; Dodge, 2006; Hawkins, 2014 \\
\hline socialism and development & Gills, 1992; Iliev \& Putterman, 2007; Wu, 2008 \\
\hline
\end{tabular}


First was the broad area of agricultural/rural development, industrial/urban development, and the relationship between the two. This arguably classic question in development studies was addressed widely across journals (e.g. Development and Change, Economic Development and Cultural Change, Journal of Development Studies, Progress in Development Studies, and World Development) and across time (e.g. from Lampard, 1955; Arrighf, 1970 to Wood \& Jordan, 2000; Iversen, Palmer-Jones, \& Sen, 2013).

Second was the subject of land reform and property rights. This included a variety of sub-topics, from the history of common property resources (Johnson, 2004; Mosse, 1997) to case studies of land reform (Binswanger \& Deininger, 1993; Logan, Tengbeh, \& Petja, 2012), global land grabs (Edelman \& León, 2013; Edelman, Oya, \& Borras, 2013), and intellectual property rights (Runge \& Defrancesco, 2006).

Third was the frequent study of colonialism's impact on development. Following the distinction between economic history and the history of economic thought, these studies reflect the distinction between development history and the history of development thought. Works falling under the former largely stemmed from historical institutionalist approaches popularized by Acemoglu, Johnson, and Robinson (2001, 2002, 2005) and Engerman and Sokoloff (1997, 2002, 2008). Examples here include Hoff (2003), Woolcock, Szreter, and Rao (2011), and Wietzske (2015). In the latter category are a number of works that trace 'false' (e.g. colonial, imperial, modernist) histories underlying development thought. These were most commonly found in reference to colonial historiographies of Africa (e.g. Chauveau \& Samba, 1989; da Silva, 2005; Fairhead \& Leach, 1995; Leach \& Fairhead, 2000; Niemeijer, 1996) and Asia (e.g. Grabowski, 1985; Mosse, 1997; Naik, 2014; Sivaramakrishnan, 2000). These works, along with a number of histories on particular development ideas, present a corpus of works on the history of development thought (see Table 4).

Table 4. Survey of histories of development thought

\begin{tabular}{ll}
\hline Historical Subject & Sample References \\
\hline $\begin{array}{l}\text { the idea } \text { of... } \\
\text { development }\end{array}$ & Arndt, 1981; Grampp, 1972; Ruttan, 1984; Watson, 2012 \\
$\begin{array}{l}\text { failed states } \\
\text { fair trade }\end{array}$ & Bilgin and Morton, 2002 \\
globalisation & Low \& Davenport, 2005 \\
nationalism & Robertson, 2004 \\
self-sufficiency & Desai, 2008 \\
sustainability & Morrissey, 1982 \\
third world/South & Harlow, Golub, \& Allenby, 2013 \\
false histories of... & Berger, 2004; Korany, 1994; Solarz, 2012 \\
$\begin{array}{l}\text { Africa } \\
\text { Asia }\end{array}$ & Chauveau \& Samba, 1989; da Silva, 2005; Fairhead \& Leach, 1995; Niemeijer, 1996 \\
US & Grabowski, 1985; Mosse, 1997; Naik, 2014; Sivaramakrishnan, 2000 \\
\hline
\end{tabular}

Fourth was the historical role of technology and innovation in development, with these subjects taking on a wide variety of forms. Examples included agricultural technology (e.g. Binswanger, 1986; 
Goossens, 1997) and innovation models for sustainable development (Lybæk, Christensen, \& Kjær, 2013). One striking example from development's earlier years even details an explicit form of ‘technological determinism' driving development (Parker, 1961).

Fifth was development history in the contexts of the global economy. Examples ranged from histories of globalization (e.g. Robertson, 2004) and the capitalist world system (e.g. Bunker \& Ciccantell, 2003; Cardoso, 2009) to econometric studies characterizing development and trade (e.g. Özler, Taymaz, \& Yilmaz, 2009; Sandberg, Seale, \& Taylor, 2006).

Finally, a sixth theme was found in historical studies of migration and development. These included perspectives from both origin countries (e.g. Beauchemin \& Schoumaker, 2009) and destination countries (e.g. Kothari, 2013). Alternatively, Baldwin-Edwards (2008) presented a historical interpretation of migration as a structural feature and not just a temporary abnormality in modern capitalism. An early study on internal resettlement in Malaysia (Dobby, 1952) also provided an intriguing glimpse into some of the anti-communist and pro-colonial sentiments colouring early development thought.

A number of less common aspects or dimensions of study - typically limited to only one or two works - were also found. Some of these were rather eclectic, such as Giulianotti and Armstrong's (2011) history of military peace-making initiatives through sporting activities. Another was Roger's (1989) study on the link between urban development and crime. Other subjects, however, were surprising in light of their prominence in the wider development discourse. Three examples stand out here: gender, education, and human rights.

In the case of gender, Benjamin and Brandt's (1995) study of women's economic roles in pre1949 China provided the only concerted history on gender and development. Other studies referenced gender, but as a secondary focus or factor, such as de Haan's (2002) case history on labour migration in Bihar, India. Peluso (2012) provided another example, using a feminist political ecology framework for a history of rubber as a socio-natural commodity.

Similarly, education often played a sideline role in historical analyses, and was rarely the concerted subject of study. Gellman (2015) offered one of the exceptions, focusing on national history education in post-conflict societies. Wietzske $(2014,2015)$ provided the others, with studies on the long-term consequences of colonial missionary education in Madagascar.

Finally, the subject of human rights continued the above pattern. Fifteen works made reference to human rights, but only three discussed the subject at length. Waltz (2002) and Szreter (2007) were two of the exceptions, with histories on the Universal Declaration of Human Rights and the right to identity registration, respectively. The third (Emmerij, Jolly, \& Weiss, 2005) discussed human rights at length, but within the contexts of UN intellectual history. 


\section{(b) Variation across temporal coverage}

In addition to subject matter, the descriptive histories can also be characterised according to their variation in temporal bounds. Some histories, for example, concentrated on very short periods of time. Dooley, Fernández-Arias, and Kletzer (1996) was one example, examining the 1980s debt crisis between 1986 and 1992. Others took a longue durée approach, spanning several centuries or more. Runge and Defrancesco (2006), for example, provided a history of common property that dated back to the eleventh-century Norman conquest of England. Akhavi's (2003) history of Islam-West relations, meanwhile, began with seventh-century Islamic communities. Finally, Arquilla's (2007) history of terrorism and unconventional warfare was perhaps the longest, referring back to the Roman Empire and through the Middle Ages.

Not all of the surveyed histories, however, adopted such a long-term perspective. When disaggregated according to historical start dates, only five per cent of the works reached back prior to the fifteenth century (see Figure 2). Another nine per cent reached back to between the fifteenth and eighteenth centuries - often in reference to early Western colonialism or globalisation (e.g. Bunker \& Ciccantell, 2003; Robertson, 2004). The second most frequently referenced starting period rested between the eighteenth and twentieth centuries, correlating to 35 per cent of the surveyed works. These often described Western historical precedents, non-Western histories, and/or particular aspects of colonialism. Humphries (2003), for example, examines the Western history of child labour as a foil for today's industrial economies. Similarly, Williamson (1979) references the Kuznets growth-versusequity relationship in US history. In contrast, Hopkins (1986) and Sivaramakrishnan (2000) document local African and Indian histories, respectively, and the effects of European colonial historiographies.

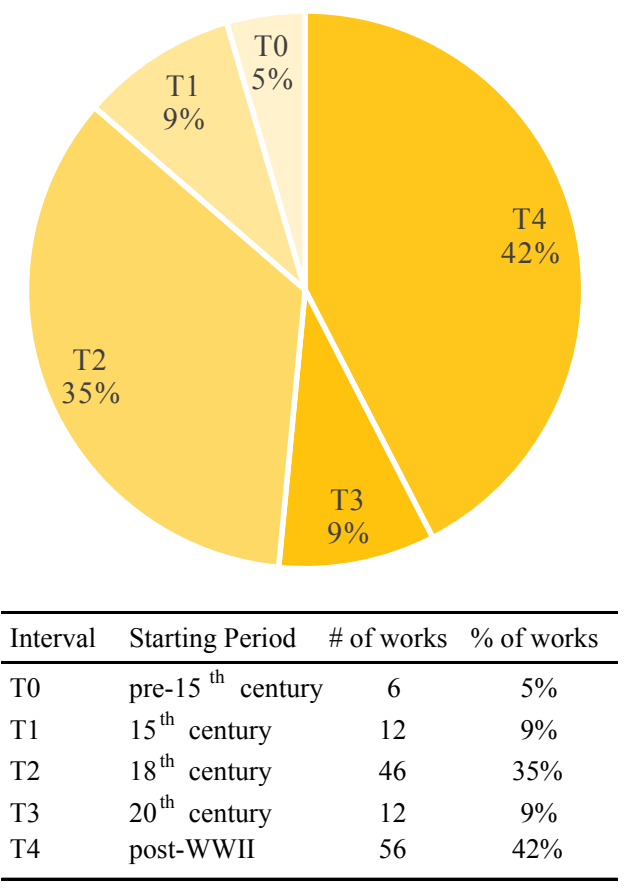

Figure 2. Temporal coverage of surveyed works ( $n=132$, four works did not apply)
Over half (51 per cent) of the works, however, began in the twentieth century, with the majority (42 per cent) situated in the post-World War II era. These can be further sub-divided into the Cold War (1945-1991) and post-Cold War (1991-) periods. Many histories produced during the Cold War reflect that era's geopolitics. Examples include Dobby's (1952) study of anti-communist resettlement in Malaysia, Sauvant's (1981) study on the New International Economic Order, and Connell-Smith's (1984) study on the US invasion of Grenada.

Histories post-1991 evidenced a number of efforts to reconcile with the sudden shifts following Soviet collapse. Gills (1992), for example, addressed speculation on socialist collapse in North Korea, while Utting (1992) described historical precedents for post-Soviet state 
reform. Korany (1994), meanwhile, offered a historical perspective on the new geopolitical challenges faced by the Third World. Finally, recent years have marked yet another shift, with histories on structural adjustment (Gills \& Philip, 1996; Berry, 1997), US hegemony (Beeson \& Higgott, 2005; Munro, 2014), and civil society (Fowler, 2000; Lewis, 2008).

\subsection{First-order historical analysis}

Histories often contain, whether implicit or explicit, a moral to their stories; that is, lessons derived through causal analysis across time and space. In our survey, the majority (89 per cent) of works contained such prescriptive arguments. The few exceptions here include what might be termed 'pure descriptive histories'. Examples include Arndt's (1981) semantic history of development or Berger's (2004) overview of Third World history. Similar to our descriptive histories, prescriptive arguments surveyed here also reflected a wide variety in subject matter. To abstract from particular focal topics, however, most of these historical lessons attempted to revise purported errors in theory and practice.

In terms of theory, Lybæk, Christensen, and Kjær (2013) provide one example that offered a model of innovation that argued against gradualist and linear assumptions to emphasize dynamic processes across multiple actors. Another was Reid's (2006) warning against assuming that democracy would entail the resolution of class conflicts and structural inequities, as argued with a case history of the Philippines. Finally, Forsyth (2007) critiqued prior assumptions of political unity within environmental movements, via examples from Thai history.

Lessons were also offered for development policy and practice. For example, Bishai and Nalubola (2002) stressed the importance of cultural integration and public-private partnership when implementing food fortification efforts. Another was Emmerij, Jolly, and Weiss (2005), who suggested a number of ways in which the UN, as an institution, might contribute to the future of development thought and action. It is also worth noting the many references to local knowledge and its practical significance. Some of these arguments stemmed from aforementioned works on false history (e.g. Fairhead \& Leach, 1995; Sivaramakrishnan, 2000). Here, colonial biases were traced to development prescriptions that harmed instead of helped. In terms of first-order lessons, these studies emphasized the importance of local knowledge in not only the implementation, but also the very conceptualization of development. Coming from more of an on-the-ground perspective, Astone (1998) also argued for closer and earlier integration of local knowledge in the planning process, based on past shortcomings in participatory development. Finally, Graulau (2008) and Logan, Tengbeh, and Petja (2012) also advised local engagement, but from the perspective of correcting for the failures of neoliberalism and modernist 'mega-narratives'.

\subsection{Second-order historical analysis}

Having summarized our findings across descriptive and first-order analyses, we now move on to our final category of second-order historiographical arguments. These moved beyond narrowly-specified 
descriptive and prescriptive topics to address development history at the general level. Namely, we find two broad sets of arguments responding to the questions of (a) why to do development history, and (b) how to do development history.

\section{(a) Why to do development history}

Arguments here entailed variants of the claim that 'history matters' (e.g. 'institutions matter', 'culture matters', 'environment matters'). Hoff (2003), for example, argues in support of the research agenda within economics to establish that institutions matter, in contrast to prior ahistorical premises. In the practical domain, McDaniel (2003) argues that history matters by showing how development practitioners have to operate in two overlapping institutional contexts. His case study on Chiquitano culture in Bolivia further extends into arguments that culture matters, demonstrating how culture can shape local distribution patterns for development aid. Mosse (1997) also comments on how culture matters through the use of a cultural ecology framework to explain common property history.

Further, arguments could be subdivided according to whether they appealed to development theory or to development practice. Johnson (2004) provided an example for development theory, calling for more history amidst an over-reliance on positivism, methodological individualism, and formal modelling in US political science. Bhatt (1976) presented complementary arguments for the field of economics. Here, history's significance was premised on the bounded nature of economic observations, the limited scope and stability of economic laws, a tendency towards over-simplified and static explanations, and the risk of fostering ideological biases. Edelman and León (2013) and Edelman, Oya, and Borras (2013) further argued for the necessity of history when it came to understanding long-term phenomena, such as land-grabbing. This was also echoed in Peluso (2012), who argued that history enables an expanded view of a particular subject's time and space, which might otherwise be missed in scientific analyses. History thus helps to overcome some of the blind spots found across various epistemic frameworks in the social sciences (Robertson, 1982). In summary, Adelman and Morris (1997) highlight the misplaced universality and the tunnel vision that arises in the absence of history. History, then, is a necessary complement to the social sciences when investigating and understanding development.

In terms of practice, Woolcock, Szreter, and Rao (2011) argued that an appreciation of history fosters a greater awareness of contexts and complexity for development action. More specifically, McDaniel (2003) and Mosse (1997) described the challenge presented by dual contexts in development scenarios (i.e. that of the development practitioner and that of the recipient). Here, history was necessary for identifying path-dependencies or development trajectories in their target contexts (Grampp, 1972; Gills \& Philip, 1996; Edelman \& León, 2013). Furthermore, as Adelman and Morris (1997) argued, development theories and policies each have their appropriate time and place. Thus, history plays a key role not only for theory building, but also for application. Lastly, Edelman 
and León (2013) and Edelman, Oya, and Borras (2013) offered a specific point on the significance of history in determining appropriate baselines for impact evaluation.

\section{(b) How to do development history}

Having addressed arguments on why to do development history, we now proceed to arguments on how. Most of the arguments surveyed here seemed to reflect lessons on how not to do history. For example, two common arguments were to be wary of over-simplification (Bhatt, 1976; Bernard, 1996; Adelman \& Morris, 1997) and of over-rationalisation (Grampp, 1972; Kaviraj, 1992; Woolcock, Szreter, \& Rao, 2011). Highlighted was the danger of over-zealously positing correlations and causations in historical analysis. For example, Grampp argued that Lord Robbins' history of economic development theory "misconceives the past because he sees it from the present and not in the way it saw itself. $[\ldots]$ He sees relations where they are not and does not notice them where they are" (Grampp, 1072: 542). There are limits to the power of reason in comprehending the complexity of the past. In doing development history, one is thus exhorted to mind the biases resulting from their own particular time and space. Accordingly, repeated calls were made to strive towards diachronic versus synchronic histories (e.g. Casanova, 1973; Grampp, 1972; Jacoby \& Kothari, 2014; Lu \& LoraWainwright, 2014; Stump, 2010).

Finally, multiple works argued for vigilance in the interpretation and production of development history, as perspective biases may also hide political biases tying knowledge to power. Peluso (2012), for example, investigated the politics of knowledge production, legitimisation, and mobilisation through case histories on how aspects of nature are commoditised and appropriated in varying social contexts. Further, the way that development concepts and the very notion of development are defined can be linked to hidden political motives. For example, Sivaramakrishnan (2000) drew links between the development discourse within forestry management and environmental histories reflecting colonial interests from nineteenth- and twentieth-century Bengal. In another, Leach and Fairhead (2000) drew from the sociology of science and public policy to show how false $20^{\text {th }}$ century histories on African deforestation have influenced present statistics, scientific analyses, and aid flows. Finally, Bilgin and Morton (2002) linked US intellectual hegemony in the social sciences to the rise of notions such as 'failed states' or 'quasi-states' as legitimate subjects of academic study. In all, these historiographical arguments warn that development history is not immune from the social, political, and intellectual climates in which they are produced. While there were no sure solutions offered (nor suggestions that they exist), it was a methodological dimension highlighted for greater awareness.

\section{DISCUSSION}

\subsection{Does the development discourse learn from history?}

Having presented our survey findings, we now return to our original question: does the development discourse learn from history? The survey certainly finds evidence of substantial interest in history 
within said discourse. However, the resulting variety and types of studies lead us to first distinguish between two different modes in which the development discourse attempts to learn from history.

In the first mode, studies look outward to external histories as a source of data. Such studies reference, for example, historical accounts of globalisation, colonisation, or migration to evaluate some aspect of development theory or practice. Indeed, the surveyed works excelled at this mode, with the majority of works utilising historical accounts in this manner. If section 3.3's surveyed critiques of a dominant positivist tendency in economic and political science are to be believed, then this result is of little surprise. This first mode of learning is highly compatible with scientific methods of investigation, in which history serves as a rich source of empirical data for theory building and evaluation.

In contrast to the first mode's outward focus on external histories, the second mode looks inward to reflect upon the history of the development discourse, itself. Examples here include Grampp's (1972) critique of Robbins' history of economic development, Arndt's (1981) semantic history of economic development, and — most recently—Woolcock, Szreter, and Rao's (2011) analysis of how and why history matters for development policy. Such works, however, were few and far in between. Further, while many of the surveyed works were critical of some aspect of development (often a form of neoliberalism or Western imperialism), critical theory did not necessarily entail critical historiography. The notable exception here and our second body of evidence were the works engaged in disentangling past ecological historiographies used to premise colonial and post-colonial development. Beyond these two sets of works, however, there was little indication of broader engagement with the history of the development discourse, itself.

With this in mind, does the development discourse learn from history? Evidence certainly suggests that it does do so in the first outward sense. That is, the discourse actively incorporates external histories as empirical evidence for development theory and practice. However, historical study of the idea of development and the discourse, itself, was rare. Consequently, this suggests that a limited but influential segment of the development discourse actively engages with external histories, but not necessarily with its own.

\subsection{Why does this matter?}

If the development discourse does indeed fail to actively learn from its own history, then what are the consequences? Why does it matter? Here, the answer is simple: it endangers the efficacy and sustainability of development theory and practice.

For one, limited awareness of development's own history impairs the ability to learn from past successes and failures. It also fosters intellectual dogmas that may impair the very ability to recognise success or failure, in the first place. Thus, claims of progress in development studies should be viewed with some scepticism if absent of historical evidence. Conceptual innovations, for example, may entail the unwitting rediscovery of old development ideas. Such claims may, even worse, belie less than 
benign attempts to repackage old wine in new bottles. A lack of broader historical reflection further impairs awareness of structural issues in the sociology and politics of development knowledge. The potential result is an ineffective discourse characterized by palliative measures and recurring crises, due to the inability to recognise and resolve more deep-rooted problems.

It is in light of this danger that historiographical research holds strategic importance for sustaining the development enterprise. Ultimately, its absence may jeopardize the development discourse and its very reason for existence - to realise the possibility of progress or development.

\subsection{What does development history do well?}

The above critique, however, should not be conflated to be an all-encompassing denouncement of the present state in development history. While it raises the possibility that influential segments of the development discourse remain largely unconscious of its own history, this does not invalidate the areas of history that the discourse does well. Namely, our survey reveals two aspects in which the development discourse excels.

First, the surveyed histories evidence a very responsive discourse. This can be seen in the breadth and timeliness of historical subjects surveyed in the aforementioned Cold War and post-Cold War periods. These included historical analyses responding to the radical shifts in the role of NGOs (e.g. Fowler 2000, Lewis 2008) or the pressing concerns with terrorism, religious fundamentalism, and multiculturalism (e.g. Akhavi, 2003; Arquilla, 2007; Beeson \& Higgott, 2005; Dodge, 2006). Thus, while the surveyed discourse may fall short in sustaining research on its own history, it has been expedient in incorporating external histories across a wide variety of concerns.

Second, this responsiveness is perhaps enabled by the diverse intellectual and multidisciplinary perspectives evidenced in the survey. This can, at least in part, be attributed to the multiple journals constituting the survey. Table 5, for example, summarises some of the distinguishing features observed across journals. 
Table 5. Some distinguishing methodological and subject features across journals

\begin{tabular}{|c|c|c|c|}
\hline Journal & \# of works & Prominent & Features \\
\hline Development and Change & 17 & $\begin{array}{l}\text { Methods } \\
\text { Subjects }\end{array}$ & $\begin{array}{l}\text { intellectual history, critical theory, in-depth case history } \\
\text { environmental history, methodology, globalization, common property }\end{array}$ \\
\hline $\begin{array}{l}\text { Economic Development and Cultural } \\
\text { Change }\end{array}$ & 11 & $\begin{array}{l}\text { Methods } \\
\text { Subjects }\end{array}$ & $\begin{array}{l}\text { intellectual history, economic history, econometrics } \\
\text { social welfare, inequality, migration, Western history }\end{array}$ \\
\hline Journal of Development Studies & 12 & $\begin{array}{l}\text { Methods } \\
\text { Subjects }\end{array}$ & $\begin{array}{l}\text { in-depth case history, ethnography, comparative history, econometrics } \\
\text { industrial development, migration, trade, institutions }\end{array}$ \\
\hline Progress in Development Studies & 6 & $\begin{array}{l}\text { Methods } \\
\text { Subjects }\end{array}$ & $\begin{array}{l}\text { critical theory, sociology } \\
\text { social theory, rural development }\end{array}$ \\
\hline $\begin{array}{l}\text { Studies in Comparative International } \\
\text { Development }\end{array}$ & 9 & $\begin{array}{l}\text { Methods } \\
\text { Subjects }\end{array}$ & $\begin{array}{l}\text { intellectual history, in-depth case history, econometrics } \\
\text { globalization, national development, political issues }\end{array}$ \\
\hline Sustainable Development & 5 & $\begin{array}{l}\text { Methods } \\
\text { Subjects }\end{array}$ & $\begin{array}{l}\text { in-depth case history, intellectual history } \\
\text { sustainability, innovation, enviroment }\end{array}$ \\
\hline Third World Quarterly & 37 & $\begin{array}{l}\text { Methods } \\
\text { Subjects }\end{array}$ & $\begin{array}{l}\text { comparative politics, in-depth case history, intellectual history } \\
\text { political issues, cultural issues, non-Western perspectives }\end{array}$ \\
\hline World Bank Economic Review & 2 & $\begin{array}{l}\text { Methods } \\
\text { Subjects }\end{array}$ & $\begin{array}{l}\text { economic history, econometrics } \\
\text { debt crisis, child labour, policy advice }\end{array}$ \\
\hline World Bank Research Observer & 4 & $\begin{array}{l}\text { Methods } \\
\text { Subjects }\end{array}$ & $\begin{array}{l}\text { economic history, econometrics } \\
\text { hyperinflation, institutions, policy advice }\end{array}$ \\
\hline World Development & 33 & $\begin{array}{l}\text { Methods } \\
\text { Subjects }\end{array}$ & $\begin{array}{l}\text { intellectual history, comparative history, ethnography, econometrics } \\
\text { rural development, colonialism, law, environmental history, policy advice }\end{array}$ \\
\hline
\end{tabular}

Development and Change, for example, was marked for its critical analyses of colonial historiographies since the 1980s (e.g. Grabowski, 1985; Chauveau \& Samba, 1989). These included many of the critical environmental historiographies of Africa and Asia produced since the mid-1990s (e.g. Leach \& Fairhead, 2000; McDaniel, 2003; Murray Li, 2002; Niemeijer, 1996; Peluso, 2012; Sivaramakrishnan, 2000).

Economic Development and Cultural Change (EDCC) was the oldest journal surveyed, dating back to 1952. Interestingly, its works exhibited notable methodological shifts over the decades. Early examples relied heavily on qualitative and historical methods, and are notable for their Western modernist biases (e.g. Dobby, 1952; Lampard, 1955; Parker, 1961; Williamson, 1979). Literature from the 1970s and early 1980s, however, produced some of the most compelling historiographical analyses in the entire survey (e.g. Arndt, 1981; Grampp, 1972). Literature since the late 1980s, however, exhibited a shift away from historiography and towards econometric analysis, alongside diversification in subject matter (e.g. Benjamin \& Brandt, 1995; Gottschang, 1987; Molini, Keyzer, van den Boom, Zant, \& Nsowah-Nuamah, 2010).

Journal of Development Studies was notable for its strong social anthropology and geography perspectives alongside emphasis of anti-reductionist and pro-historical views during the 1970s and 1980s (e.g. Arrighf, 1970; Harriss \& Harriss, 1984; Schmitz, 1984). Similar to the EDCC literature, works surveyed since the 1990s exhibited a diversification in development topics and increased prevalence of econometric methods - though not to the extent of EDCC. 
Progress in Development Studies was the newest journal surveyed, with its first issue published in 2001. Partly due to a special issue that produced three out of six of the journal's surveyed works, its works carried a heavy emphasis on sociology and critical theory.

Studies in Comparative International Development produced a rather eclectic mix of methodological approaches in its historical works. The most distinguishing feature observed here was a responsiveness to political contexts, such as Peloso's (1972) questioning of US historiography amidst third world objections, Morrissey's (1982) history of agricultural self-sufficiency amidst the shift to basic needs, and Allende's (1988) history on the tension between Pinochet's neoliberal views versus incumbent Latin American attitudes towards privatization.

Sustainable Development was the second most recent journal published, dating back to 1993. Here, our survey found relatively few historical works. Common to the works that were found was a relative emphasis on innovation and technology, in addition to environmental and broader ecological perspectives (e.g. Goossens, 1997; Lybæk, Christensen, \& Kjær, 2013).

Third World Quarterly produced the most historical works in the survey, with a total of 37 articles. In contrast to the predominance of economics in development studies, this journal was marked for its pronounced emphasis on politics, foreign policy, and international relations. Economic issues were invariably treated in political or social contexts, with a complete absence of econometric studies. In contrast to early EDCC works, the literature here predominantly gave voice to non-Western perspectives, though Western historical views were not entirely absent (e.g. Arquilla, 2007; Watson, 2012).

The World Bank Research Observer and the World Bank Economic Review produced the fewest results despite publication since 1986. Early works provide some of the few macroeconomic and finance-oriented works surveyed here (e.g. Dooley, Fernández-Arias, \& Kletzer, 1996; Solimano, 1990). This is perhaps of little surprise given the World Bank's historical preference for neoclassical economic methods and subject matter. More recent works, however, evidence a broadening in perspectives (e.g. Hayami, 2001; Humphries, 2003). Though few in number, these works held merit in presenting clear guidance for policy and practice.

Finally, World Development produced the second most number of works, with a total of 33 articles. These exhibited diverse methodological approaches, similar to Journal of Development Studies, though with more comparative analyses. Early volumes from the 1970s and 1980s produced relatively few historical works. However, the late 1980s mark a turning point, with historical works growing in frequency across subsequent decades. The subjects of study proved diverse, covering not only economic (e.g. trade, fiscal policy) and social issues (e.g. migration, social welfare), but also political subjects, as well (e.g. democracy, civil society). Noted here were a number of critical environmental historiographies, joining those found in Development and Change (e.g. Fairhead \& Leach, 1995; Stump, 2010) 
Though some journals seemed to favor certain subjects or approaches over others, their combined output evidences a diverse and responsive discourse, on the whole. Thus, despite the more obvious methodological conflicts between 'scientific' versus 'situated' views, the histories observed here represented an impressive breadth of epistemological orientations from across the social sciences. Accordingly, it would be another kind of failure in critical reflection to disregard such strengths and overzealously throw the baby out with the bathwater, so to speak.

\subsection{What now?}

To be clear, we do not wish to pose historical self-consciousness within development studies as the next cure-all for development problems. Rather, the above arguments have attempted to illustrate history's more subtle but far-reaching benefits for development theory and practice. As argued in the history and philosophy of science, history can serve a highly complementary role in advancing theory (Chang, 2004). In particular, it can help recover overlooked ideas and lessons in development's past, while moderating theoretical dogmas and their consequent polemics. What needs to be done, then, to realize such benefits?

We thus close with two suggestions for future work. The first is further investigation to examine whether other sectors of the broader development discourse also remain similarly unengaged with the development discourse's past. Corollary to this is further consideration of the concrete ways in which development theorists, policymakers, and practitioners stand to gain from reflective histories of development thought. If history is to occupy space in the development discourse, it ought to make clear its value for neighbouring efforts and its commitment to proving its worth. In this respect, the surveyed work by Woolcock, Szreter, and Rao (2011) stands out as an exemplary step in this direction. Alongside such works as Adelman and Morris (1997), Arndt (1981), and Grampp (1972), there are a number of opportunities for continuing this conversation.

The second suggestion for future work lies in the organization of concerted historical dialogue within the larger development discourse. This is an area where opportunities lie for those willing to bring together the various efforts scattered across time and disciplinary space. Some of the precedents and original researchers to constitute this specialised discourse have already been identified in this survey. Many other individuals and works exist, however, in the broader development discourse and in neighbouring domains (e.g. Cooper, 2010; Cullather, 2000; Frey \& Kunkel, 2011). Such efforts would need to be brought together not only in the literature, but also in person (e.g. conferences, seminars, workshops). Otherwise, past, present, and future efforts may end up lost in relative obscurity—like ships passing each other in the night. 


\section{CONCLUSION}

Amidst a development enterprise now more than 70 years in the making and not without signs of institutional aging, we have examined here whether development learns from history. To do so, we surveyed 136 articles from 10 leading development studies journals spanning the period from 1952 to 2016. We found significant diversity and interest in historical research within this literature. Through the survey, we produced a basic typology distinguishing between descriptive historical accounts, firstorder historical lessons, and second-order historiographical arguments. After reviewing each type of historical analysis, we found a very active use of history to respond to pressing issues of the times. Further, the multidisciplinary nature of these efforts produced a diversity of views and methodological approaches.

However, while the survey evidenced an active use of external histories, it did not necessarily find the same when it came to development's own. The two notable exceptions were an eclectic mix of intellectual histories of particular development ideas and the critical investigations on colonial historiography. In the overall survey, however, such works were few and far in between - though highly insightful when found. Consequently, there was little evidence of sustained dialogue reflecting upon the broader history of the development discourse, itself. This suggests a relative unconsciousness about the myriad ways in which we have talked about and engaged with the idea of development in the past up to the present. The practical consequence of this is the risk of repeating past proposals, past mistakes, and past critiques without realizing it - a sort of institutional amnesia inhibiting the efficacy, legitimacy, and sustainability of the development endeavor.

The major disclaimer here, of course, is whether the study's findings are indeed true. Methodologically, the study can only comment on a narrow — though influential—slice of the development discourse as it flows through leading peer-reviewed English-language journals. Further work is warranted to examine other strands in the development discourse, whether in the realm of theory, policy, or practice. If it does hold true that the development discourse remains largely unreflective of its past, then this paper calls for two actions. The first is for more in-depth investigation as to why the more historically enlightened arguments evidenced here have not garnered more attention in the past and the present. The second is for organisation across past and present efforts to sustain a concerted discourse on development's own history and to provide insights for theorists, policymakers, and practitioners, alike.

A development discourse that is largely unaware of its past bodes poorly for its future. For better or worse, development is now part of twentieth-century history. If it is to be effective and sustainable in the twenty-first, then it will need to reflect upon this past in order to envision its better future. The present survey finds that it generally does not. The presence of some exceptional past works suggests that it can. A case has been made here for why it must, ultimately resting on development's efficacy and the possibility of progress. 


\section{REFERENCES}

Acemoglu, D., Johnson, S. and Robinson, J. (2001). The colonial origins of comparative development: An empirical investigation. American Economic Review, 91(5), 1369-1402.

Acemoglu, D., Johnson, S. and Robinson, J. (2002). Reversal of fortune: Geography and institutions in the making of the world income distribution. Quarterly Journal of Economics, 117(4), 1231-94.

Acemoglu, D., Johnson, S. and Robinson, J. (2005). Institutions as the fundamental cause of long-run growth. In P. Aghion \& S. Durlauf (eds.), Handbook of economic growth, Vol. IA (385-472). Amsterdam: Elsevier.

Adelman, I., \& Morris, C. T. (1997). Editorial: Development history and its implications for development theory. World Development. http://doi.org/10.1016/S0305-750X(97)00010-7

Akhavi, S. (2003). Islam and the West in world history. Third World Quarterly, 24(3), 545-562. http://doi.org/10.1080/0143659032000084465

Alcántara, C. H. de. (1974). The "Green Revolution" as history: the Mexican experience*. Development and Change, 5(2), 25-44. http://doi.org/10.1111/j.1467-7660.1974.tb00655.x

Allende, J. A. (1988). Historical constraints to privatization: The case of the nationalized chilean copper industry. Studies In Comparative International Development, 23(1), 55-84. http://doi.org/10.1007/BF02686999

Arndt, H. W. (1981). Economic Development: A Semantic History. Economic Development and Cultural Change, 29(3), 457-466. http://doi.org/10.1086/451266

Arndt, H. W. (1989). Economic development: The history of an idea. University of Chicago Press.

Arquilla, J. (2007). The end of war as we knew it? Insurgency, counterinsurgency and lessons from the forgotten history of early terror networks. Third World Quarterly, 28(2), 369-386. http://doi.org/10.1080/01436590601153861

Arrighf, G. (1970). Labour supplies in historical perspective: A study of the proletarianization of the African peasantry in Rhodesia*. Journal of Development Studies, 6(3), 197-234. http://doi.org/10.1080/00220387008421322

Astone, J. (1998). Incorporating local history into planning documents: A case study from Guinea, West Africa. World Development, 26(9), 1773-1784. http://doi.org/10.1016/S0305750X(98)00073-4

Baldwin-Edwards, M. (2008). Towards a theory of illegal migration: Historical and structural components. Third World Quarterly, 29(7), 1449-1459.

Beauchemin, C., \& Schoumaker, B. (2009). Are Migrant Associations Actors in Local Development? A National Event-History Analysis in Rural Burkina Faso. World Development, 37(12), $1897-$ 1913. http://doi.org/10.1016/j.worlddev.2009.03.012 
Beeson, M., \& Higgott, R. (2005). Hegemony, institutionalism and US foreign policy: theory and practice in comparative historical perspective. Third World Quarterly, 26(7), 1173-1188. http://doi.org/10.1080/01436590500235777

Benjamin, D., \& Brandt, L. (1995). Markets, Discrimination, and the Economic Contribution of Women in China: Historical Evidence. Economic Development and Cultural Change, 44(1), 63104. http://doi.org/10.1086/452201

Berger, M. T. (2004). After the Third World? History, destiny and the fate of Third Worldism. Third World Quarterly, 25(1), 9-39. http://doi.org/10.1080/0143659042000185318

Bernard, M. (1996). States, social forces, and regions in historical time: Toward a critical political economy of Eastern Asia. Third World Quarterly, 17(4), 649-666.

Berry, S. (1997). Tomatoes, land and hearsay: Property and history in Asante in the time of structural adjustment. World Development, 25(8), 1225-1241.

Bhatt, V. V. (1976). Economic development: An analytic-historical approach. World Development, $4(7), 583-592$.

Bieber, F. (2000). Bosnia-Herzegovina and Lebanon: Historical lessons of two multireligious states. Third World Quarterly, 21(2), 269-281. http://doi.org/10.1080/01436590050004355

Bilgin, P., \& Morton, A. D. (2002). Historicising representations of "failed states": Beyond the coldwar annexation of the social sciences? Third World Quarterly, 23(1), 55-80. http://doi.org/10.1080/01436590220108172

Binswanger, H. (1986). AGRICULTURAL MECHANIZATION. The World Bank Research Observer, 1(1), 27-56. http://doi.org/10.1093/wbro/1.1.27

Binswanger, H. P., \& Deininger, K. (1993). South African land policy: The legacy of history and current options. World Development, 21(9), 1451-1475. http://doi.org/10.1016/0305750X(93)90127-U

Bishai, D., \& Nalubola, R. (2002). The History of Food Fortification in the United States: Its Relevance for Current Fortification Efforts in Developing Countries. Economic Development and Cultural Change, 51(1), 37-53. http://doi.org/10.1086/345361

Blaney, D. L., \& Pasha, M. K. (1993). Civil society and democracy in the third world: Ambiguities and historical possibilities. Studies in Comparative International Development, 28(1), 3-24. http://doi.org/10.1007/BF02743770

Broad, R., \& Heckscher, Z. (2003). Before Seattle: The historical roots of the current movement against corporate-led globalisation. Third World Quarterly, 24(4), 713-728. http://doi.org/10.1080/0143659032000105849

Bunker, S. G., \& Ciccantell, P. S. (2003). Generative sectors and the new historical materialism: Economic ascent and the cumulatively sequential restructuring of the world economy. Studies in Comparative International Development, 37(4), 3-30. http://doi.org/10.1007/BF02686270 
Cardoso, F. H. (2009). New Paths: Globalization in Historical Perspective. Studies in Comparative International Development, 44(4), 296-317. http://doi.org/10.1007/s12116-009-9050-3

Casanova, P. G. (1973). Historical systems and social systems. Studies in Comparative International Development, 8(3), 227-246. http://doi.org/10.1007/BF02800431

Chaiken, M. S. (1998). Primary Health Care initiatives in colonial Kenya. World Development, 26(9), 1701-1717. http://doi.org/10.1016/S0305-750X(98)00067-9

Chang, H. (2004). Inventing temperature: Measurement and scientific progress. Oxford: Oxford University Press.

Chauveau, J.-P., \& Samba, A. (1989). Market Development, Government Interventions and the Dynamics of the Small-Scale Fishing Sector: An Historical Perspective of the Senegalese Case. Development and Change, 20(4), 599-620. http://doi.org/10.1111/j.1467-7660.1989.tb00359.x Collins, R. (2009). The sociology of philosophies. Harvard University Press.

Connell-Smith, G. (1984). The Grenada Invasion in Historical Perspective: From Monroe to Reagan. Third World Quarterly, 6(2), 432-445. http://doi.org/10.1080/01436598408419775

Cooper, F. (2010). Writing the History of Development. Journal of Modern European History, 8(1), $5-23$.

Cullather, N. (2000). Research Note: Development? It's History. Diplomatic History, 24(4), 641-653. da Silva, T. S. (2005). Narrating a White Africa: autobiography, race and history. Third World Quarterly, 26(3), 471-478. http://doi.org/10.1080/01436590500033784

Dawson, A. (2013). The Social Determinants of the Rule of Law: A Comparison of Jamaica and Barbados. World Development, 45, 314-324. http://doi.org/10.1016/j.worlddev.2012.12.016

de Haan, A. (2002). Migration and Livelihoods in Historical Perspective: A Case Study of Bihar, India. Journal of Development Studies, 38(5), 115-142. http://doi.org/10.1080/00220380412331322531

Desai, R. (2008). Introduction: nationalisms and their understandings in historical perspective. Third World Quarterly, 29(3), 397-428. http://doi.org/10.1080/01436590801931413

Dobby, E. H. G. (1952). Resettlement Transforms Malaya: A Case-History of Relocating the Population of an Asian Plural Society. Economic Development and Cultural Change, 1(3), $163-$ 189. http://doi.org/10.1086/449617

Dodge, T. (2006). Iraq: The contradictions of exogenous state-building in historical perspective. Third World Quarterly, 27(1), 187-200. http://doi.org/10.1080/01436590500370061

Dooley, M., Fernandez-Arias, E., \& Kletzer, K. (1996). Is the Debt Crisis History? Recent Private Capital Inflows to Developing Countries. The World Bank Economic Review, 10(1), 27-50. http://doi.org/10.1093/wber/10.1.27

Edelman, M., \& León, A. (2013). Cycles of Land Grabbing in Central America: an argument for history and a case study in the Bajo Aguán, Honduras. Third World Quarterly, 34(9), 16971722. http://doi.org/10.1080/01436597.2013.843848 
Edelman, M., Oya, C., \& Borras, S. M. (2013). Global Land Grabs: historical processes, theoretical and methodological implications and current trajectories. Third World Quarterly, 34(9), 15171531. http://doi.org/10.1080/01436597.2013.850190

Emmerij, L., Jolly, R., \& Weiss, T. G. (2005). Economic and Social Thinking at the UN in Historical Perspective. Development and Change, 36(2), 211-235. http://doi.org/10.1111/j.0012155X.2005.00409.X

Engerman, S. L., \& Sokoloff, K. L. (1997). Factor endowments, institutions, and differential paths of growth among new world economies: A View from economic historians of the United States. In S. Haber (ed.), How Latin America fell behind: Essays on the economic histories of Brazil and Mexico, 1800-1914 (260-304). Stanford: Stanford University Press.

Engerman, S. and Sokoloff, K. (2002). Factor endowments, inequality, and paths of development among New World economies. Economica, 3(1), 41-109.

Engerman, S. and Sokoloff, K. (2008). Debating the role of institutions in political and economic development: theory, history, and findings. Annual Review of Political Science, 11, 199-235.

Escobar, A. (2011). Encountering development: The making and unmaking of the Third World. Princeton: Princeton University Press.

Esteva, G. (2010). Development. In W. Sachs (Ed.), The development dictionary: A guide to knowledge as power (1-23). London: Zed Books.

Fairhead, J., \& Leach, M. (1995). False forest history, complicit social analysis: Rethinking some West African environmental narratives. World Development, 23(6), 1023-1035. http://doi.org/10.1016/0305-750X(95)00026-9

Forsyth, T. (2007). Are Environmental Social Movements Socially Exclusive? An Historical Study from Thailand. World Development, 35(12), 2110-2130. http://doi.org/10.1016/j.worlddev.2007.01.005

Fowler, A. (2000). NGDOs as a moment in history: Beyond aid to social entrepreneurship or civic innovation?. Third World Quarterly, 21(4), 637-654.

Frey, M., \& Kunkel, S. (2011). Writing the History of Development: A Review of the Recent Literature. Contemporary European History, 20(2), 215-232.

Gellman, M. (2015). Teaching silence in the schoolroom: whither national history in Sierra Leone and El Salvador? Third World Quarterly, 36(1), 147-161. http://doi.org/10.1080/01436597.2014.976027

Gerring, J., Kingstone, P., Lange, M., \& Sinha, A. (2011). Democracy, History, and Economic Performance: A Case-Study Approach. World Development, 39(10), 1735-1748. http://doi.org/10.1016/j.worlddev.2011.04.029

Gills, B. (1992). North Korea and the crisis of socialism: The historical ironies of national division. Third World Quarterly, 13(1), 107-130. http://doi.org/10.1080/01436599208420265 
Gills, B., \& Philip, G. (1996). Editorial: Towards convergence in development policy?: Challenging the 'Washington Consensus' and restoring the historicity of divergent development trajectories. Third World Quarterly, 17(4), 585-591.

Giulianotti, R., \& Armstrong, G. (2011). Sport, the Military and Peacemaking: history and possibilities. Third World Quarterly, 32(3), 379-394. http://doi.org/10.1080/01436597.2011.573935

Gooch, E. (2016). Estimating the Long-Term Impact of the Great Chinese Famine (1959-61) on Modern China. World Development. http://doi.org/10.1016/j.worlddev.2016.08.006

Goode, R. (1993). Tax advice to developing countries: An historical survey. World Development, 21(1), 37-53. http://doi.org/10.1016/0305-750X(93)90135-V

Goossens, F. (1997). FAILING INNOVATION IN THE ZAIRIAN CASSAVA PRODUCTION SYSTEM: A COMPARATIVE HISTORICAL ANALYSIS. Sustainable Development, 5(1), 3642. http://doi.org/10.1002/(SICI)1099-1719(199703)5:1<36::AID-SD60>3.0.CO;2-D

Gottschang, T. R. (1987). Economic Change, Disasters, and Migration: The Historical Case of Manchuria. Economic Development and Cultural Change, 35(3), 461-490. http://doi.org/10.1086/451600

Grabowski, R. (1985). A Historical Reassessment of Early Japanese Development. Development and Change, 16(2), 235-250. http://doi.org/10.1111/j.1467-7660.1985.tb00209.x

Grampp, W. D. (1972). Robbins on the History of Development Theory. Economic Development and Cultural Change, 20(3), 539-553. http://doi.org/10.1086/450573

Graulau, J. (2008). “Is mining good for development?”: the intellectual history of an unsettled question. Progress in Development Studies, 8(2), 129-162. JOUR. http://doi.org/10.1177/146499340700800201

Harlow, J., Golub, A., \& Allenby, B. (2013). A Review of Utopian Themes in Sustainable Development Discourse. Sustainable Development, 21(4), 270-280. http://doi.org/10.1002/sd.522

Harriss, B., \& Harriss, J. (1984). "Generative" or "parasitic" urbanism? Some observations from the recent history of a South Indian market town. Journal of Development Studies, 20(3), 82-101. http://doi.org/10.1080/00220388408421907

Hatton, T. J., \& Williamson, J. G. (2008). The Impact of Immigration: Comparing Two Global Eras. World Development, 36(3), 345-361. http://doi.org/10.1016/j.worlddev.2007.04.009

Hawkins, J. R. (2014). Historicizing the state in development theory: Michael Mann's model of social power. Progress in Development Studies, 14(3), 299-308. JOUR. http://doi.org/10.1177/1464993414521333

Hayami, Y. (2001). Ecology, History, and Development: A Perspective from Rural Southeast Asia. The World Bank Research Observer, 16(2), 169-198. http://doi.org/10.1093/wbro/16.2.169 
Hirschmann, D. (1999). Development Management versus Third World Bureaucracies: A Brief History of Conflicting Interests. Development and Change, 30(2), 287. http://doi.org/10.1111/1467-7660.00118

Hoff, K. (2003). Paths of Institutional Development: A View from Economic History. The World Bank Research Observer, 18(2), 205-226. http://doi.org/10.1093/wbro/lkg006

Hopkins, A. G. (1986). The World Bank in Africa: Historical reflections on the African present. World Development, 14(12), 1473-1487.

Humphries, J. (2003). Child Labor: Lessons from the Historical Experience of Today's Industrial Economies. The World Bank Economic Review, 17(2), 175-196. http://doi.org/10.1093/wber/lhg016

Iliev, P., \& Putterman, L. (2007). Social Capability, History and the Economies of Communist and Postcommunist States. Studies in Comparative International Development, 42(1-2), 36-66. http://doi.org/10.1007/s12116-007-9002-8

Iversen, V., Palmer-Jones, R., \& Sen, K. (2013). On the Colonial Origins of Agricultural Development in India: A Re-examination of Banerjee and Iyer, "History, Institutions and Economic Performance." Journal of Development Studies, 49(12), 1631-1646. http://doi.org/10.1080/00220388.2013.807502

Jacoby, T., \& Kothari, U. (2014). Introduction: Bringing social theory back into issues of development. Progress in Development Studies, 14(3), 215-220. JOUR. http://doi.org/10.1177/1464993414521337

Johnson, C. (2004). Uncommon Ground: The "Poverty of History" in Common Property Discourse. Development and Change, 35(3), 407-434. http://doi.org/10.1111/j.1467-7660.2004.00359.x

Jolly, R., Emmerij, L., Ghai, D., \& Lapeyre, F. (2004). UN contributions to development thinking and practice (Vol. 5). Indiana University Press.

Kaviraj, S. (1992). Marxism and the Darkness of History. Development and Change, 23(3), 79-102. http://doi.org/10.1111/j.1467-7660.1992.tb00457.x

Korany, B. (1994). End of history, or its continuation and accentuation? The global South and the "new transformation" literature. Third World Quarterly, 15(1), 7-15. http://doi.org/10.1080/01436599408420360

Kothari, U. (2013). Geographies and Histories of Unfreedom: Indentured Labourers and Contract Workers in Mauritius. Journal of Development Studies, 49(8), 1042-1057. http://doi.org/10.1080/00220388.2013.780039

Lampard, E. E. (1955). The History of Cities in the Economically Advanced Areas. Economic Development and Cultural Change, 3(2), 81-136. http://doi.org/10.1086/449680

Leach, M., \& Fairhead, J. (2000). Fashioned Forest Pasts, Occluded Histories? International Environmental Analysis in West African Locales. Development and Change, 31(1), 35-59. http://doi.org/10.1111/1467-7660.00146 
Lewis, D. (2008). Crossing the Boundaries between "Third Sector" and State: life-work histories from the Philippines, Bangladesh and the UK. Third World Quarterly, 29(1), 125-141. http://doi.org/10.1080/01436590701726582

Leys, C. (1996). The rise and fall of development theory. Indiana University Press.

Logan, B. I., Tengbeh, G., \& Petja, B. (2012). Towards a reorientation in land reform: From a market to locality-driven approach in South Africa's land restitution programme. Progress in Development Studies, 12(2-3), 173-191. JOUR. http://doi.org/10.1177/146499341101200306

Love, J. L. (1989). Modeling internal colonialism: History and prospect. World Development, 17(6), 905-922. http://doi.org/10.1016/0305-750X(89)90011-9

Low, W., \& Davenport, E. (2005). Postcards from the edge: maintaining the "alternative" character of fair trade. Sustainable Development, 13(3), 143-153. http://doi.org/10.1002/sd.275

Lu, J., \& Lora-Wainwright, A. (2014). Historicizing Sustainable Livelihoods: A Pathways Approach to Lead Mining in Rural Central China. World Development, 62, 189-200. http://doi.org/10.1016/j.worlddev.2014.05.006

Ludden, D. (2012). Imperial Modernity: history and global inequity in rising Asia. Third World Quarterly, 33(4), 581-601. http://doi.org/10.1080/01436597.2012.657419

Lybaek, R., Christensen, T. B., \& Kjaer, T. (2013). Governing Innovation for Sustainable Development in the Danish Biogas Sector - a Historical Overview and Analysis of Innovation. Sustainable Development, 21(3), 171-182. http://doi.org/10.1002/sd.1548

Malloch-Brown, M. (2014). Foreword. In S. Browne \& T. G. Weiss (Eds.), Post-2015 UN development: Making change happen? (pp. xv-xvi). New York: Routledge.

McDaniel, J. M. (2003). History and the Duality of Power in Community-based Forestry in Southeast Bolivia. Development and Change, 34(2), 339-356. http://doi.org/10.1111/1467-7660.00308

McLure, C. E. (1992). Income tax reform in Colombia and Venezuela: A comparative history. World Development, 20(3), 351-367. http://doi.org/10.1016/0305-750X(92)90029-U

Meier, G. M. (2004). Biography of a subject: An evolution of development economics. Oxford University Press.

Molini, V., Keyzer, M., van den Boom, B., Zant, W., \& Nsowah-Nuamah, N. (2010). Safety Nets and Index-Based Insurance: Historical Assessment and Semiparametric Simulation for Northern Ghana. Economic Development and Cultural Change, 58(4), 671-712. http://doi.org/10.1086/652476

Morrissey, M. (1982). Agricultural self-sufficiency: The recent history of an idea. Studies In Comparative International Development, 17(1), 73-95. http://doi.org/10.1007/BF02687278

Mosse, D. (1997). The Symbolic Making of a Common Property Resource: History, Ecology and Locality in a Tank-irrigated Landscape in South India. Development and Change, 28(3), 467504. http://doi.org/10.1111/1467-7660.00051 
Munro, J. (2014). US foreign policy, intersectional totality and the structure of empire. Third World Quarterly, 35(9), 1566-1581. http://doi.org/10.1080/01436597.2014.970865

Murray Li, T. (2002). Local Histories, Global Markets: Cocoa and Class in Upland Sulawesi. Development and Change, 33(3), 415-437. http://doi.org/10.1111/1467-7660.00261

Mushtaq, U. (2015). The political economy of Intra-Kashmir Trade. Progress in Development Studies, 15(2), 139-153. JOUR. http://doi.org/10.1177/1464993414565531

Naik, P. (2014). The case of the "other India" and Indian IR scholarship. Third World Quarterly, 35(January 2015), 1496-1508. http://doi.org/10.1080/01436597.2014.946271

Niemeijer, D. (1996). The Dynamics of African Agricultural History: Is it Time for a New Development Paradigm? Development and Change, 27(1), 87-110. http://doi.org/10.1111/j.1467-7660.1996.tb00579.x

North, D. C. (1989). Institutions and economic growth: An historical introduction. World Development, 17(9), 1319-1332. http://doi.org/10.1016/0305-750X(89)90075-2

Omgba, L. D. (2015). Why Do Some Oil-Producing Countries Succeed in Democracy While Others Fail? World Development, 76, 180-189. http://doi.org/10.1016/j.worlddev.2015.07.005

Özler, Ş., Taymaz, E., \& YIlmaz, K. (2009). History Matters for the Export Decision: Plant-Level Evidence from Turkish Manufacturing Industry. World Development, 37(2), 479-488. http://doi.org/10.1016/j.worlddev.2008.04.003

Parker, W. N. (1961). Economic Development in Historical Perspective. Economic Development and Cultural Change, 10(1), 1-7. http://doi.org/10.1086/449937

Peloso, V. (1972). A third world perspective on the writing of united states history for the 1970s. Studies in Comparative International Development, 7(1), 85-90. http://doi.org/10.1007/BF02810983

Peluso, N. L. (2012). What's Nature Got To Do With It? A Situated Historical Perspective on Socionatural Commodities. Development and Change, 43(1), 79-104. http://doi.org/10.1111/j.14677660.2012.01755.x

Peralta, P. O., \& Hollenstein, P. (2015). Territorial Coalitions and Rural Dynamics in Eduador: Why history matters. World Development, 73, 85-95.

Pieterse, J. N. (2010). Development theory. Sage.

Preston, P. W. (1999). Development theory: An introduction. Siglo XXI.

Rapley, J. (1997). Understanding development: Theory and practice in the third world. Psychology Press.

Reid, B. (2006). Historical blocs and democratic impasse in the Philippines: 20 years after 'people power'. Third World Quarterly, 27(6), 1003-1020.

Rist, G. (2014). The history of development: from western origins to global faith. Zed books.

Robertson, A. F. (1982). Abusa: The structural history of an economic contract. Journal of Development Studies, 18(4), 447-478. http://doi.org/10.1080/00220388208421840 
Robertson, R. (2004). The Historical Context and Significance of Globalization. Development and Change, 35(3), 557-565. http://doi.org/10.1111/j.1467-7660.2004.00366.x

Rogers, J. D. (1989). Theories of crime and development: An historical perspective. Journal of Development Studies, 25(3), 314-328. http://doi.org/10.1080/00220388908422114

Runge, C. F., \& Defrancesco, E. (2006). Exclusion, Inclusion, and Enclosure: Historical Commons and Modern Intellectual Property. World Development, 34(10), 1713-1727. http://doi.org/10.1016/j.worlddev.2006.02.002

Sachs, W. (2010). Introduction. In W. Sachs (Ed.), The development dictionary: A guide to knowledge as power ( $\mathrm{xv}-\mathrm{xx})$. London: Zed Books.

Sandberg, H. M., Seale, J. L., \& Taylor, T. G. (2006). History, regionalism, and CARICOM trade: A gravity model analysis. Journal of Development Studies, 42(5), 795-811. http://doi.org/10.1080/00220380600741995

Santayana, G. (1905). The life of reason: Introduction, and reason in common sense. New York: Scribner.

Sauvant, K. P. (1981). From economic to socio-cultural emancipation: The historical context of the new international economic order and the new international socio-cultural order. Third World Quarterly, 3(1), 48-61. http://doi.org/10.1080/01436598108419542

Schmitz, H. (1984). Industrialisation strategies in less developed countries: Some lessons of historical experience. Journal of Development Studies, 21(1), 1-21. http://doi.org/10.1080/00220388408421928

Singer, H. W. (1953). The Brazilian Salte Plan: An Historical Case Study of the Role of Internal Borrowing in Economic Development. Economic Development and Cultural Change, 1(5), 341349. http://doi.org/10.1086/449635

Sivaramakrishnan, K. (2000). State Sciences and Development Histories: Encoding Local Forestry Knowledge in Bengal. Development and Change, 31(1), 61-89. http://doi.org/10.1111/14677660.00147

Solarz, M. W. (2012). "Third World": the 60th anniversary of a concept that changed history. Third World Quarterly, 33(9), 1561-1573. http://doi.org/10.1080/01436597.2012.720828

Solimano, A. (1990). INFLATION AND THE COSTS OF STABILIZATION. The World Bank Research Observer, 5(2), 167-185. http://doi.org/10.1093/wbro/5.2.167

Stump, D. (2010). “Ancient and Backward or Long-Lived and Sustainable?” The Role of the Past in Debates Concerning Rural Livelihoods and Resource Conservation in Eastern Africa. World Development, 38(9), 1251-1262. http://doi.org/10.1016/j.worlddev.2010.02.007

Szreter, S. (2007). The Right of Registration: Development, Identity Registration, and Social Security-A Historical Perspective. World Development, 35(1), 67-86. http://doi.org/10.1016/j.worlddev.2006.09.004 
Thomson Reuters. (2016). Journal Citation Reports@ Social Sciences Edition. <URL: http://ipscience.thomsonreuters.com/cgi-bin/jrnlst/jloptions.cgi?PC=K>.

Udall, A. (1980). Urbanization and rural labor supply: A historical study of Bogotá, Colombia since 1920. Studies In Comparative International Development, 15(3), 70-83. http://doi.org/10.1007/BF02686467

Utting, P. (1992). From orthodoxy to reform: Historical experiences of post-revolutionary societies. Third World Quarterly, 13(1), 43-65. http://doi.org/10.1080/01436599208420261

Waltz, S. (2002). Reclaiming and rebuilding the history of the Universal Declaration of Human Rights. Third World Quarterly, 23(3), 437-448. http://doi.org/10.1080/01436590220138378

Watson, M. (2012). Friedrich List's Adam Smith Historiography and the Contested Origins of Development Theory. Third World Quarterly, 33(3), 459-474. http://doi.org/10.1080/01436597.2012.657482

Weiss, T. G., \& Abdenur, A. E. (2014). Introduction: Emerging powers and the UN-what kind of development partnership?. Third World Quarterly, 35(10), 1749-1758.

Wiemers, A. (2015). A "Time of Agric": Rethinking the "Failure" of Agricultural Programs in 1970s Ghana. World Development, 66, 104-117. http://doi.org/10.1016/j.worlddev.2014.08.006

Wietzke, F.-B. (2014). Historical Origins of Uneven Service Supply in Sub-Saharan Africa. The Role of Non-State Providers. Journal of Development Studies, 50(12), 1614-1630. http://doi.org/10.1080/00220388.2014.936398

Wietzke, F.-B. (2015). Long-Term Consequences of Colonial Institutions and Human Capital Investments: Sub-National Evidence from Madagascar. World Development, 66, 293-307. http://doi.org/10.1016/j.worlddev.2014.08.010

Williamson, J. G. (1979). Inequality, Accumulation, and Technological Imbalance: A Growth-Equity Conflict in American History? Economic Development and Cultural Change, 27(2), 231-253. http://doi.org/10.1086/451090

Wood, A., \& Jordan, K. (2000). Why Does Zimbabwe Export Manufactures and Uganda Not? Econometrics Meets History. Journal of Development Studies, 37(2), 91-116. http://doi.org/10.1080/713600070

Woolcock, M., Szreter, S., \& Rao, V. (2011). How and Why Does History Matter for Development Policy? Journal of Development Studies, 47(1), 70-96. http://doi.org/10.1080/00220388.2010.506913

Wu, G. (2008). From Post-imperial to Late Communist Nationalism: historical change in Chinese nationalism from May Fourth to the 1990s. Third World Quarterly, 29(3), 467-482. http://doi.org/10.1080/01436590801931454

Ziai, A. (2015). Development Discourse and Global History: From Colonialism to the Sustainable Development Goals. Routledge. 